\title{
SYNE2 wt Allele
}

National Cancer Institute

\section{Source}

National Cancer Institute. SYNE2 wt Allele. NCI Thesaurus. Code C120061.

Human SYNE2 wild-type allele is located in the vicinity of $14 q 23.2$ and is approximately $373 \mathrm{~kb}$ in length. This allele, which encodes nesprin-2 protein, is involved in the structure, organization, and localization of the nucleus. Variation of the gene is associated with Emery-Dreifuss muscular dystrophy type 5. 